\title{
The Role of Energy Storage with Renewable Electricity Generation (Report Summary)
}

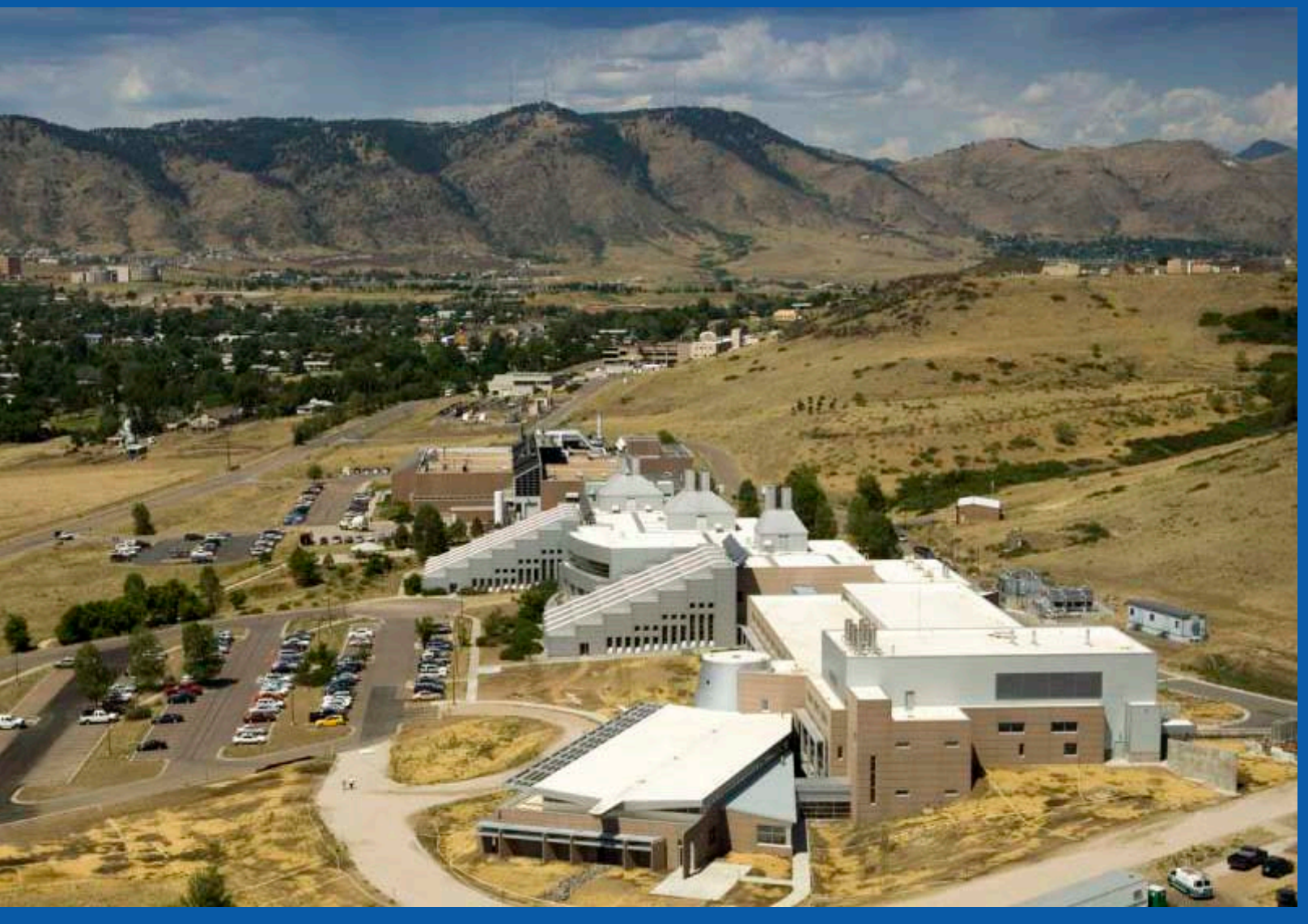

Paul Denholm Erik Ela Brendan Kirby Michael Milligan

March 2010 NREL/PR-6A2-49396 


\section{Outline}

- Operation of the Electric Grid

- Electricity Storage in the Existing Grid

- Impacts of Renewables on the Grid and the Role of Enabling Technologies

- Storage and Flexibility Options for RenewableDriven Grid Applications

- Conclusions 


\section{Operation of the Electric Grid}

- Supply must always meet demand

- Large hourly and season variations in electricity demand

- Operating reserve requirements to maintain system stability and reliability 


\section{Large Demand Variability}

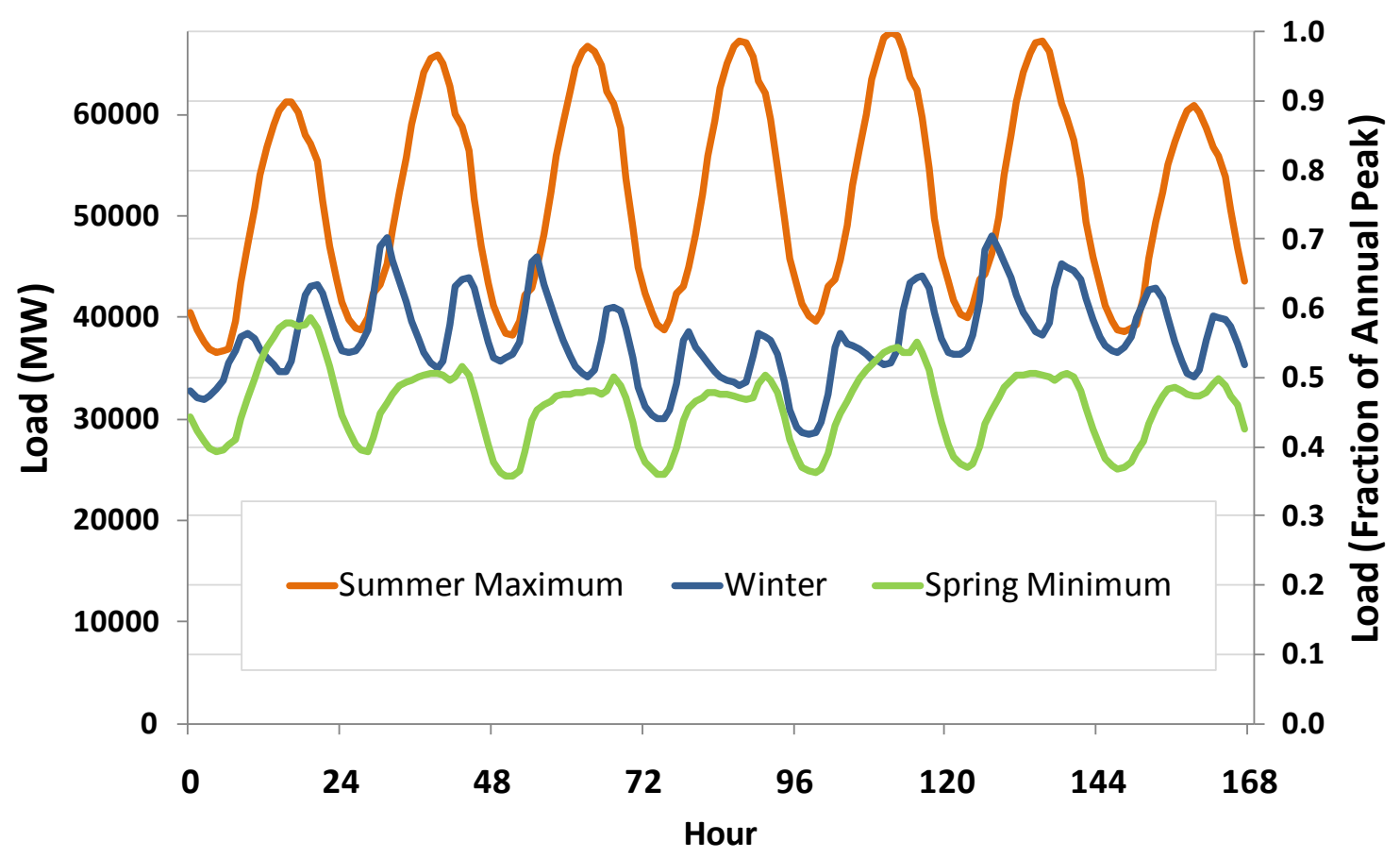

Hourly electricity demand for three weeks in the ERCOT (Texas) Grid in 2005

Requires multiple generator types: baseload, load-following (intermediate load and peaking) 


\section{Reserve Requirements}

- Provides stable and reliable operation

- Not uniformly defined

- Frequency Regulation

- Serves the random, rapid variation around the normal load

- Highest value

- Contingency Reserve (often referred to as spinning reserves)

- Quickly replaces a lost generator or transmission line

- Infrequently called $\sim 1 \mathrm{x} /$ week for about 10 minutes 


\section{Frequency Regulation Requirements}

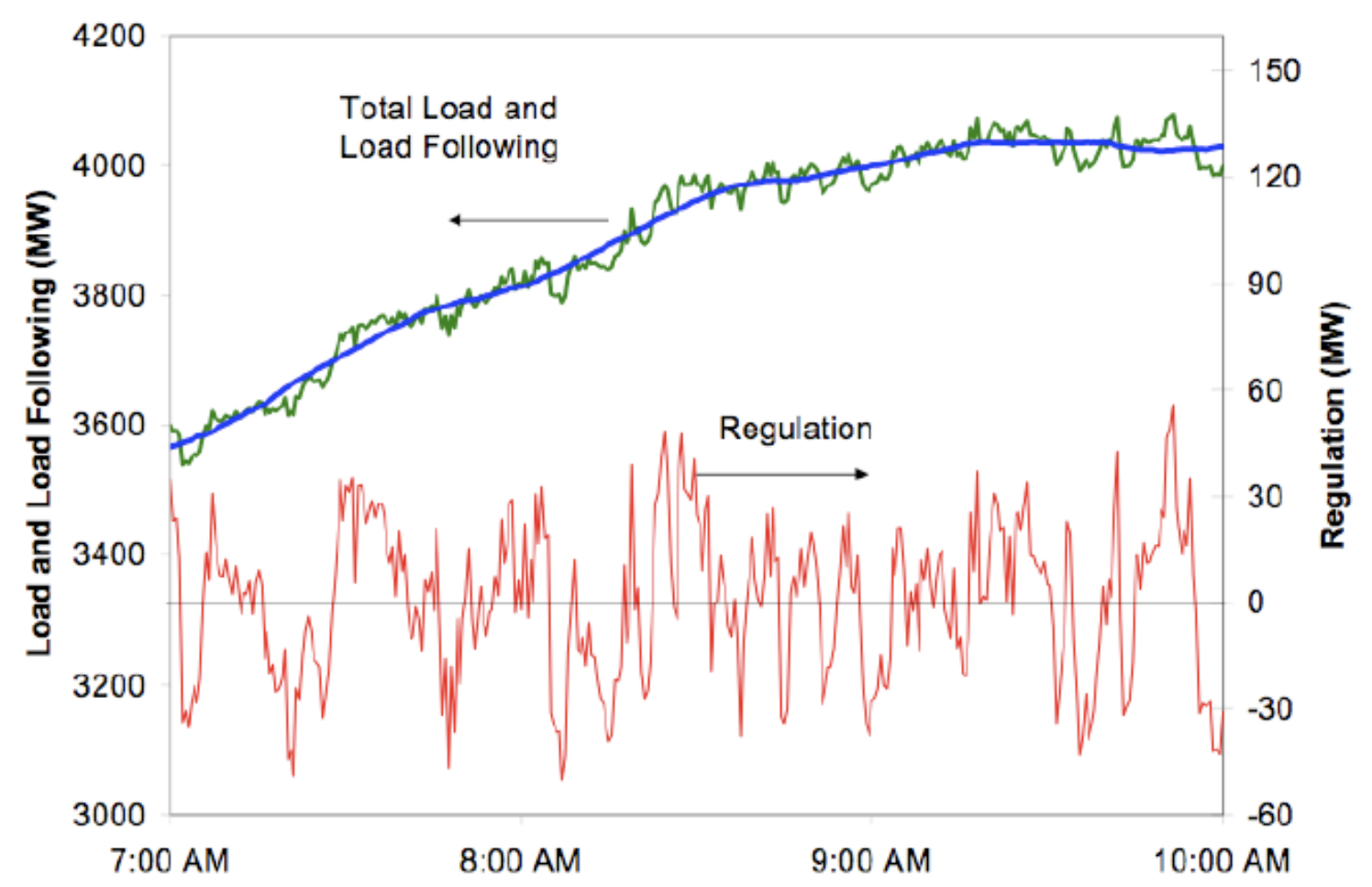

System load following and regulation. Regulation (red) is the fast fluctuating component of total load (green) while load following (blue) is the slower trend 


\section{Reserve Requirements Add Costs}

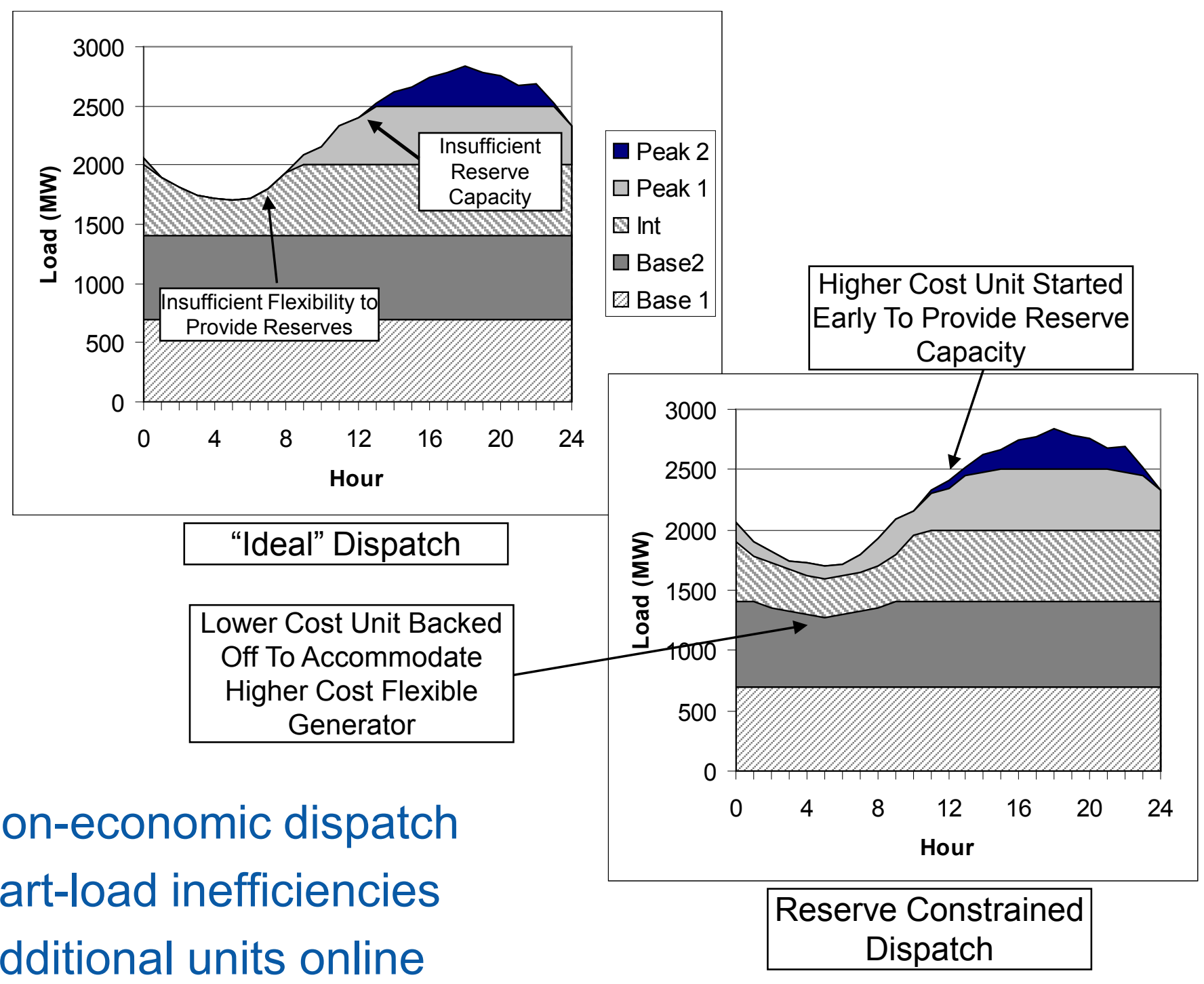




\section{Energy Storage in the Existing Grid}

- Historical motivations

- Renewed interest due to emergence of restructured markets

- Applications of energy storage 


\section{Electricity Storage in the Existing Grid}

Historical motivations (pre-1980)

- Storage provides load following and reserves, while increasing use of low-cost baseload plants

- Limited options for peaking and intermediate load generation

- Increasing cost of natural gas and oil

- Restrictions on use of oil and natural gas (Power Plant and Industrial Fuel Use Act)

- Low-efficiency oil and steam gas plants as opposed to today's efficient gas turbines

- Anticipated construction of many nuclear plants providing low cost (but inflexible) baseload energy 


\section{Pumped Hydro}

Was an attractive alternative to other load-following generators

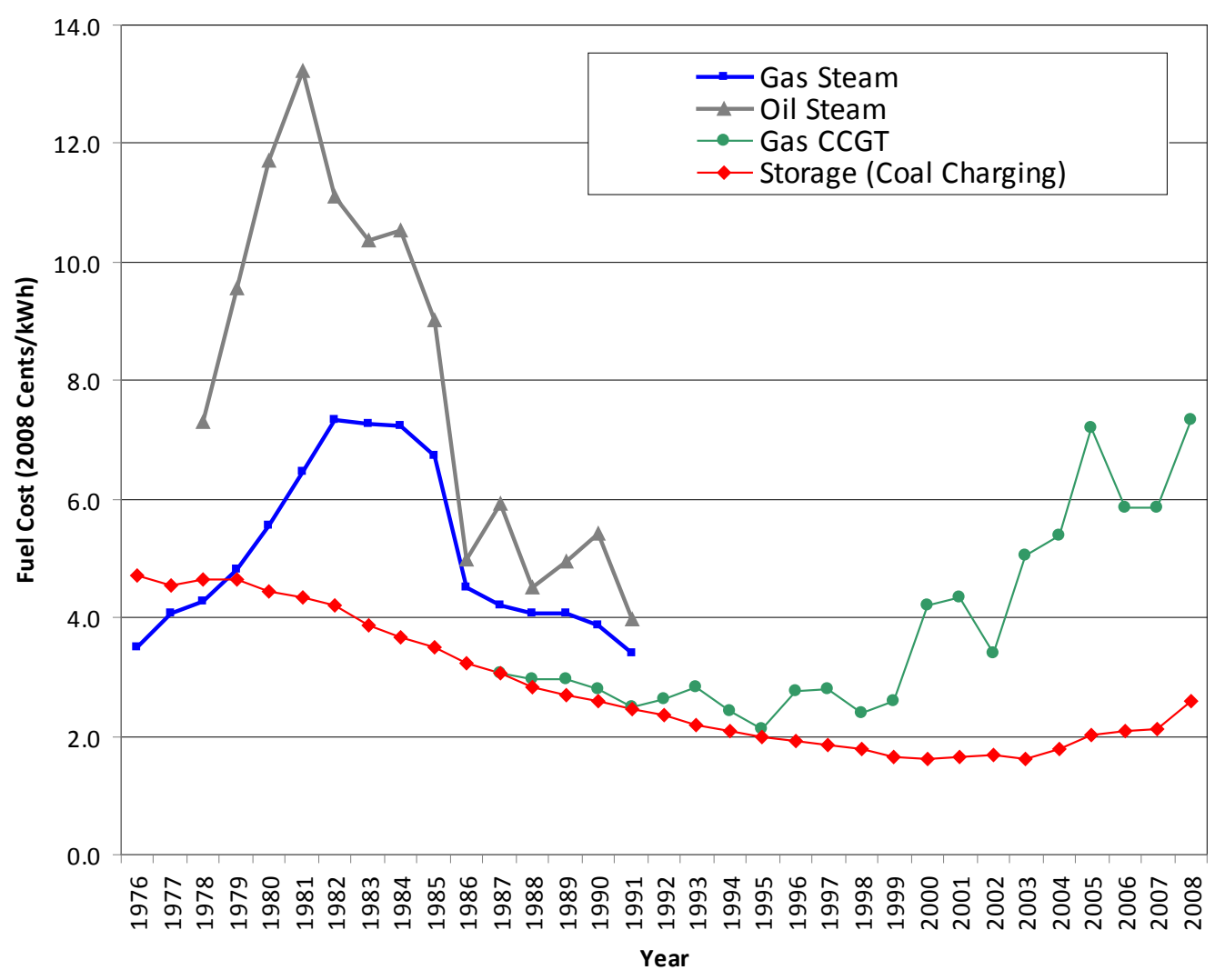

Variable costs of storage are less than from oil or gas

Pumped hydro costs during this period (before 1980) are comparable to combined-cycle gas generators 


\section{Limited Storage Built after 1980}

- Collapse of oil and gas prices

- Repeal of fuel use act

- High-efficiency low cost gas turbines become available

- Storage development limited to $20 \mathrm{GW}$ of pumped hydro storage, 1 CAES plant plus a few batteries and demonstration projects 


\section{Revised Interest in Energy Storage}

- Advances in storage technologies

- Increases in fossil fuel prices

- Energy markets

- T\&D siting challenges

- Perceived need for storage with renewables 


\section{Value of Storage in Restructured Markets}

Historical Values of Energy Storage in Restructured Electricity Markets

\begin{tabular}{|l|l|l|l|l|}
\hline $\begin{array}{l}\text { Market } \\
\text { Evaluated }\end{array}$ & Location & $\begin{array}{l}\text { Years } \\
\text { Evaluated }\end{array}$ & $\begin{array}{l}\text { Annual Value } \\
(\$ / \mathrm{kW})\end{array}$ & Assumptions \\
\hline $\begin{array}{l}\text { Energy } \\
\text { Arbitrage }\end{array}$ & PJM $^{\mathrm{a}}$ & $2002-2007$ & $\$ 60-\$ 115$ & $\begin{array}{l}12 \text { hour, 80\% efficient device. Range of } \\
\text { efficiencies and sizes evaluated }[1]\end{array}$ \\
\cline { 2 - 5 } & NYISO & $2001-2005$ & $\begin{array}{l}\$ 87-\$ 240 \\
(\mathrm{NYC}) \\
\$ 29-\$ 84 \\
(\mathrm{rest})\end{array}$ & $\begin{array}{l}10 \text { hour, 83\% efficient device. Range of } \\
\text { efficiencies and sizes evaluated. }\end{array}$ \\
\cline { 2 - 5 } & USA & $1997-2001$ & $\$ 37-\$ 45$ & $80 \%$ efficient device, Covers NE, No Cal, PJM \\
\cline { 2 - 5 } & CA $^{\mathrm{d}}$ & 2003 & $\$ 49$ & 10 hour, 90\% efficient device. \\
\hline \multirow{2}{*}{$\begin{array}{l}\text { Regulation } \\
\text { NYISO }\end{array}$} & $2001-2005$ & $\$ 163-248$ & PJM, NYISO, ERCOT, ISONE \\
\cline { 2 - 5 } & USA & $2003-2006$ & $\$ 236-\$ 429$ & PJM, NYISO, ERCOT, ISONE \\
\hline $\begin{array}{l}\text { Contingency } \\
\text { Reserves }\end{array}$ & USA & $2004-2005$ & $\$ 66-\$ 149$ & \\
\hline
\end{tabular}

a Sioshansi et al. 2009

b Walawalkar et al. 2007

c Figueiredo et al. 2006

d Eyer et al. 2004

e Denholm and Letendre 2007 


\section{Historical Value of Energy Storage in U.S. Markets}

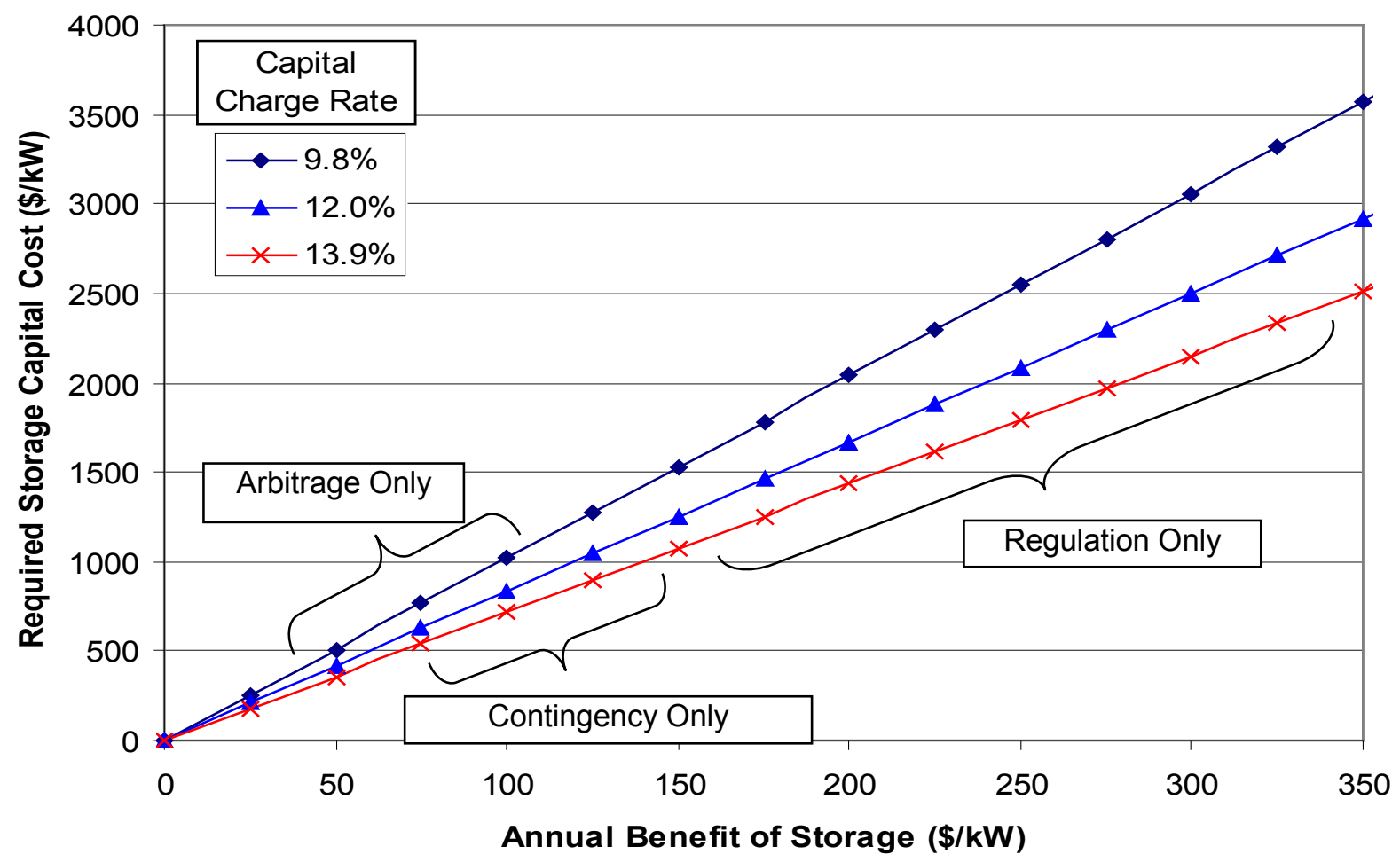

Relationship between total installed cost and annualized cost

Greatest value is frequency regulation - focus of many applications (flywheels, vehicle to grid). Arbitrage alone is generally insufficient to support most storage technologies, which are generally $>\$ 1,000 / \mathrm{kW}$ 


\section{Applications of Energy Storage}

\begin{tabular}{|c|c|c|}
\hline Application & Description & Timescale of Operation \\
\hline $\begin{array}{l}\text { Load Leveling/ } \\
\text { Arbitrage }\end{array}$ & $\begin{array}{l}\text { Purchasing low-cost off-peak energy and selling it } \\
\text { during periods of high prices. }\end{array}$ & Response in minutes to hours. Discharge time of hours. \\
\hline Firm Capacity & $\begin{array}{l}\text { Provide reliable capacity to meet peak system } \\
\text { demand. }\end{array}$ & Must be able to discharge continuously for several hours or more. \\
\hline \multicolumn{3}{|l|}{ Operating Reserves } \\
\hline Regulation & $\begin{array}{l}\text { Fast responding increase or decrease in } \\
\text { generation (or load) to respond to random, } \\
\text { unpredictable variations in demand. }\end{array}$ & $\begin{array}{l}\text { Unit must be able to respond in seconds to minutes. Discharge time is typically minutes. Service is } \\
\text { theoretically "net zero" energy over extended time periods. }\end{array}$ \\
\hline $\begin{array}{l}\text { Contingency } \\
\text { Spinning } \\
\text { Reserve }^{[1]}\end{array}$ & $\begin{array}{l}\text { Fast response increase in generation (or } \\
\text { decrease load) to respond to a contingency such } \\
\text { as a generator failure. }\end{array}$ & $\begin{array}{l}\text { Unit must begin responding immediately and be fully responsive within } 10 \text { minutes. Must be able to } \\
\text { hold output for } 30 \text { minutes to } 2 \text { hours depending on the market. Service is infrequently called. [2] }\end{array}$ \\
\hline $\begin{array}{l}\text { Replacement/ } \\
\text { Supplemental }\end{array}$ & Units brought on-line to replace spinning units. & $\begin{array}{l}\text { Typical response time requirement of 30-60 minutes depending on market minutes. Discharge time } \\
\text { may be several hours. }\end{array}$ \\
\hline $\begin{array}{l}\text { Ramping/Load } \\
\text { Following }\end{array}$ & $\begin{array}{l}\text { Follow longer term (hourly) changes in electricity } \\
\text { demand. }\end{array}$ & Response time in minutes to hours. Discharge time may be minutes to hours. \\
\hline $\begin{array}{l}\text { T\&D Replacement } \\
\text { and Deferral }\end{array}$ & $\begin{array}{l}\text { Reduce loading on T\&D system during peak } \\
\text { times. }\end{array}$ & Response in minutes to hours. Discharge time of hours. \\
\hline Black-Start & $\begin{array}{l}\text { Units brought online to start system after a } \\
\text { system-wide failure (blackout). }\end{array}$ & $\begin{array}{l}\text { Response time requirement is several minutes to over an hour. Discharge time requirement may be } \\
\text { several to many hours. }{ }^{[3]}\end{array}$ \\
\hline $\begin{array}{l}\text { End-Use Applications } \\
\text { TOU Rates } \\
\text { Demand Charge } \\
\text { Reduction }\end{array}$ & $\begin{array}{l}\text { Functionally the same as arbitrage, just at the } \\
\text { customer site. } \\
\text { Functionally the same as firm capacity, just at the } \\
\text { customer site. }\end{array}$ & $\begin{array}{l}\text { Same as arbitrage. } \\
\text { Same as firm capacity. }\end{array}$ \\
\hline $\begin{array}{l}\text { Backup Power/ } \\
\text { UPS/Power Quality }\end{array}$ & $\begin{array}{l}\text { Functionally the same as contingency reserve, } \\
\text { just at the customer site. }\end{array}$ & nstantaneous response. Discharge time depends on level of reliability needed by customer. \\
\hline
\end{tabular}




\section{Impacts of Renewables on the Grid}

- Storage is often perceived as "necessary" for renewables to achieve a large $(>10 \%$ ? $>20 \%$ ?) penetration.

- Renewables are seen as a source of value for storage

- Can renewables be used without storage?

- How do renewables impact the grid? 


\section{Impacts of Renewables on the Grid}

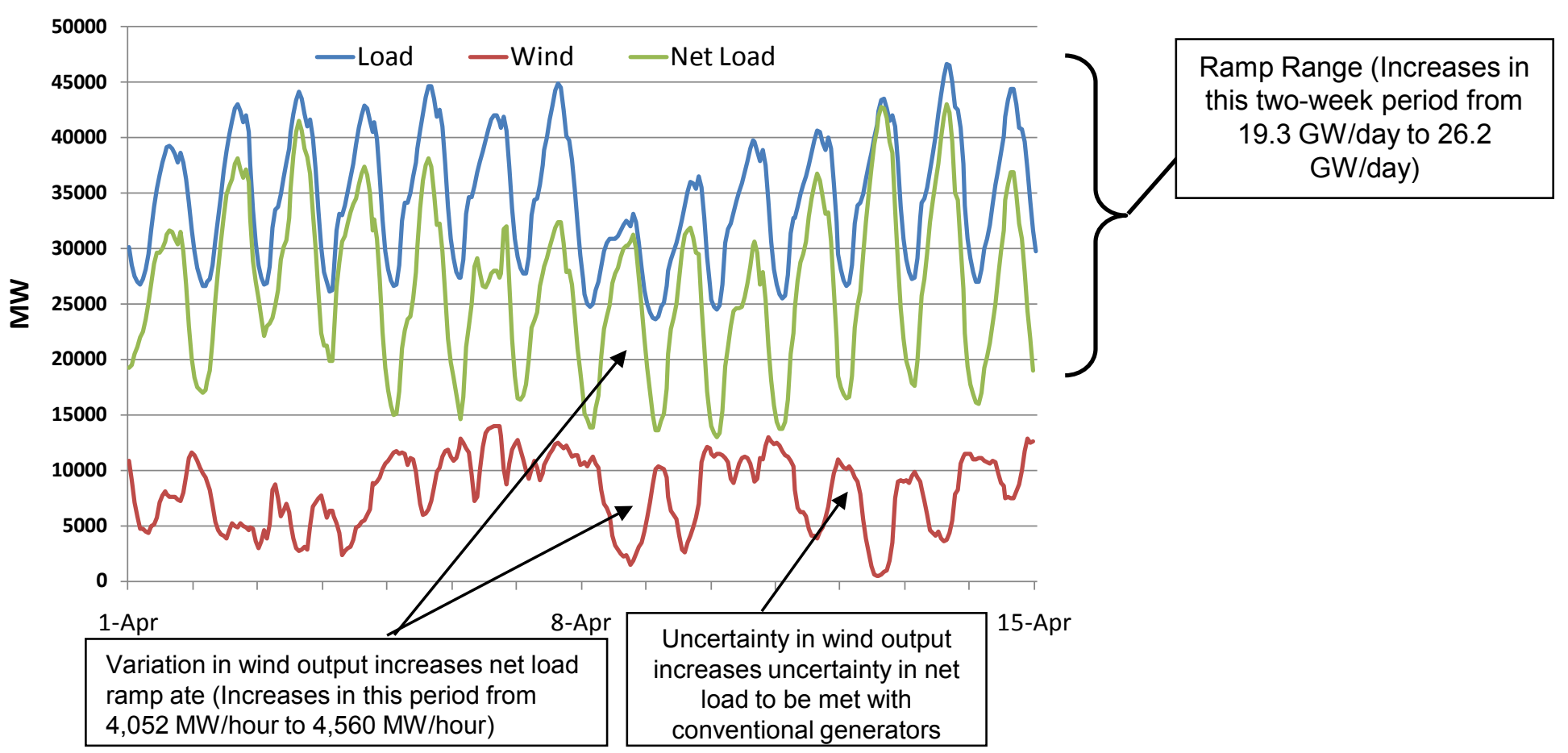

Four major impacts of variable generation (VG) on the grid:

1) Increased need for frequency regulation

2) Increase in hourly ramp rate

3) Increase in uncertainty of net load

4) Increase in ramp range 


\section{Costs of Wind Integration}

- Simulate system with and without solar and wind

- Use unit commitment software includes existing generation mix, transmission system

- Use lots of wind and solar simulations to consider spatial diversity

- May involve substantial costs

- Evaluate costs of:

- Additional regulation reserves

- Additional load following

- Wind uncertainty

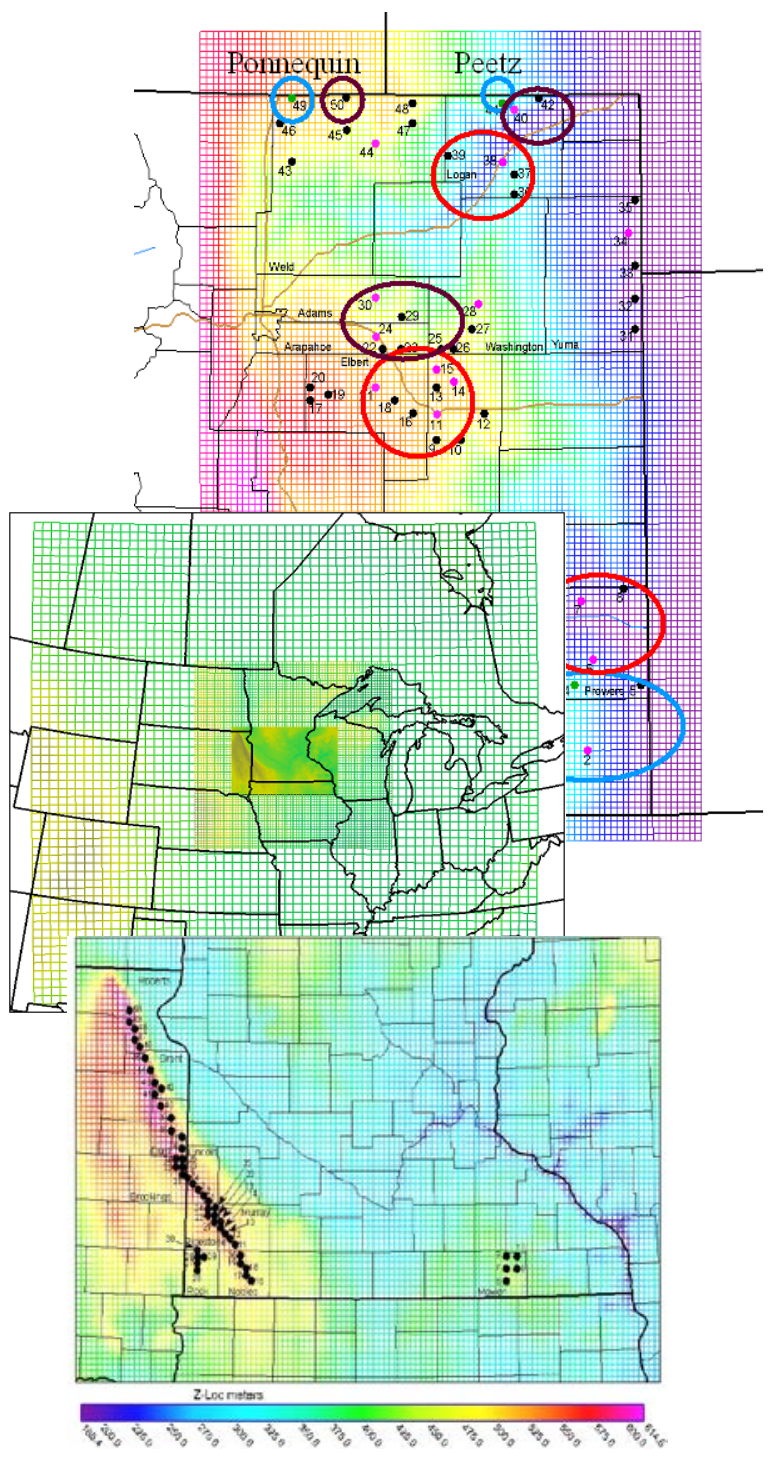




\section{Costs of Wind Integration}

\begin{tabular}{|c|c|c|c|c|c|c|c|}
\hline Date & Study & $\begin{array}{l}\text { Wind Capacity } \\
\text { Penetration } \\
(\%)\end{array}$ & $\begin{array}{l}\text { Regulation } \\
\text { Cost } \\
\text { (\$/MWh) }\end{array}$ & $\begin{array}{l}\text { Load- } \\
\text { Following Cost } \\
(\$ / \mathrm{MWh})\end{array}$ & $\begin{array}{c}\text { Unit } \\
\text { Commitment } \\
\text { Cost }(\$ / M W h)\end{array}$ & $\begin{array}{c}\text { Other } \\
(\$ / M W h)\end{array}$ & $\begin{array}{l}\text { Total Oper. } \\
\text { Cost Impact } \\
\text { (\$/MWh) }\end{array}$ \\
\hline 2003 & Xcel-UWIG & 3.5 & 0 & 0.41 & 1.44 & $\mathrm{Na}$ & 1.85 \\
\hline 2003 & WE Energies & 29 & 1.02 & 0.15 & 1.75 & $\mathrm{Na}$ & 2.92 \\
\hline 2004 & Xcel-MNDOC & 15 & 0.23 & na & 4.37 & $\mathrm{Na}$ & 4.6 \\
\hline 2005 & PacifiCorp-2004 & 11 & 0 & 1.48 & 3.16 & $\mathrm{Na}$ & 4.64 \\
\hline 2006 & Calif. (multi-year)a & 4 & 0.45 & trace & trace & $\mathrm{Na}$ & 0.45 \\
\hline 2006 & Xcel-PSCob & 15 & 0.2 & na & 3.32 & 1.45 & 4.97 \\
\hline 2006 & MN-MISOC & 36 & na & na & na & na & 4.41 \\
\hline 2007 & Puget Sound Energy & 12 & na & na & na & na & 6.94 \\
\hline 2007 & Arizona Pub. Service & 15 & 0.37 & 2.65 & 1.06 & na & 4.08 \\
\hline 2007 & Avista Utilities $^{d}$ & 30 & 1.43 & 4.4 & 3 & na & 8.84 \\
\hline 2007 & Idaho Power & 20 & na & na & na & na & 7.92 \\
\hline 2007 & PacifiCorp-2007 & 18 & na & 1.1 & 4 & na & 5.1 \\
\hline 2008 & Xcel-PSCo ${ }^{e}$ & 20 & na & na & na & na & 8.56 \\
\hline
\end{tabular}

a Regulation costs represent 3-year average.

b The Xcel/PSCO study also examine the cost of gas supply scheduling. Wind increases the uncertainty of gas requirements and may increase costs of gas supply contracts.

c Highest over 3 -year evaluation period. $30.7 \%$ capacity penetration corresponding to $25 \%$ energy penetration

d Unit commitment includes cost of wind forecast error.

e This integration cost reflects a $\$ 10 / M M B t u$ natural gas scenario. This cost is much higher than the integration cost calculated for Xcel-PSCo in 2006, in large measure due to the higher natural gas price: had the gas price from the 2006 study been used in the 2008 study, the integration cost would drop from $\$ 8.56 / \mathrm{MWh}$ to $\$ 5.13 / \mathrm{MWh}$. 


\section{Conclusions of Wind Integration Studies}

\section{( $<30 \%$ Penetration)}

- Challenges are unit commitment, regulation and load following

- Integration costs are modest (typically less than \$5/MWh)

- Increased variability can be accommodates by existing generator flexibility and other "low-cost" flexibility such as increased balancing area cooperation (balancing wind generation and load over larger areas to "share" the increased variability.

- Spatial diversity smooth's aggregated wind output reducing short-term fluctuations to hour time scales

- Storage would "help" but is not needed, and the integration costs would not "pay" for currently expensive storage technologies. 


\section{Limits to VG Penetration - Curtailment}

- At high penetration, economic limits will be due to curtailment

- Limited coincidence of VG supply and normal demand

- Minimum load constraints on thermal generators

- Thermal generators kept online for operating reserves

- Results from EWITS and WWSIS, along with other studies, indicate that beyond 30\% VG, new sources of flexibility will be needed 


\section{High Penetration Limits}

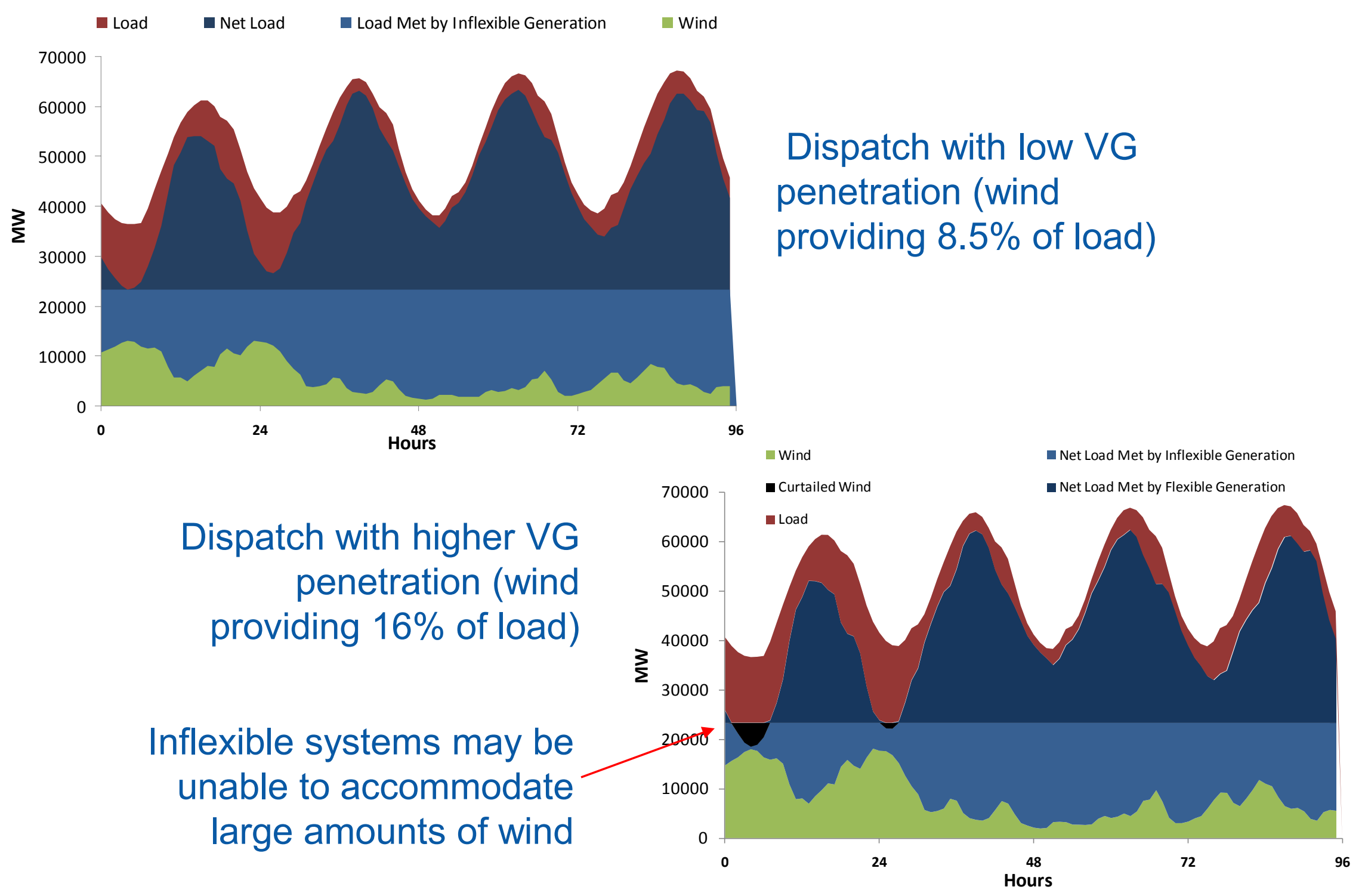




\section{Current System Flexibility}

\section{Limited by Baseload Capacity}

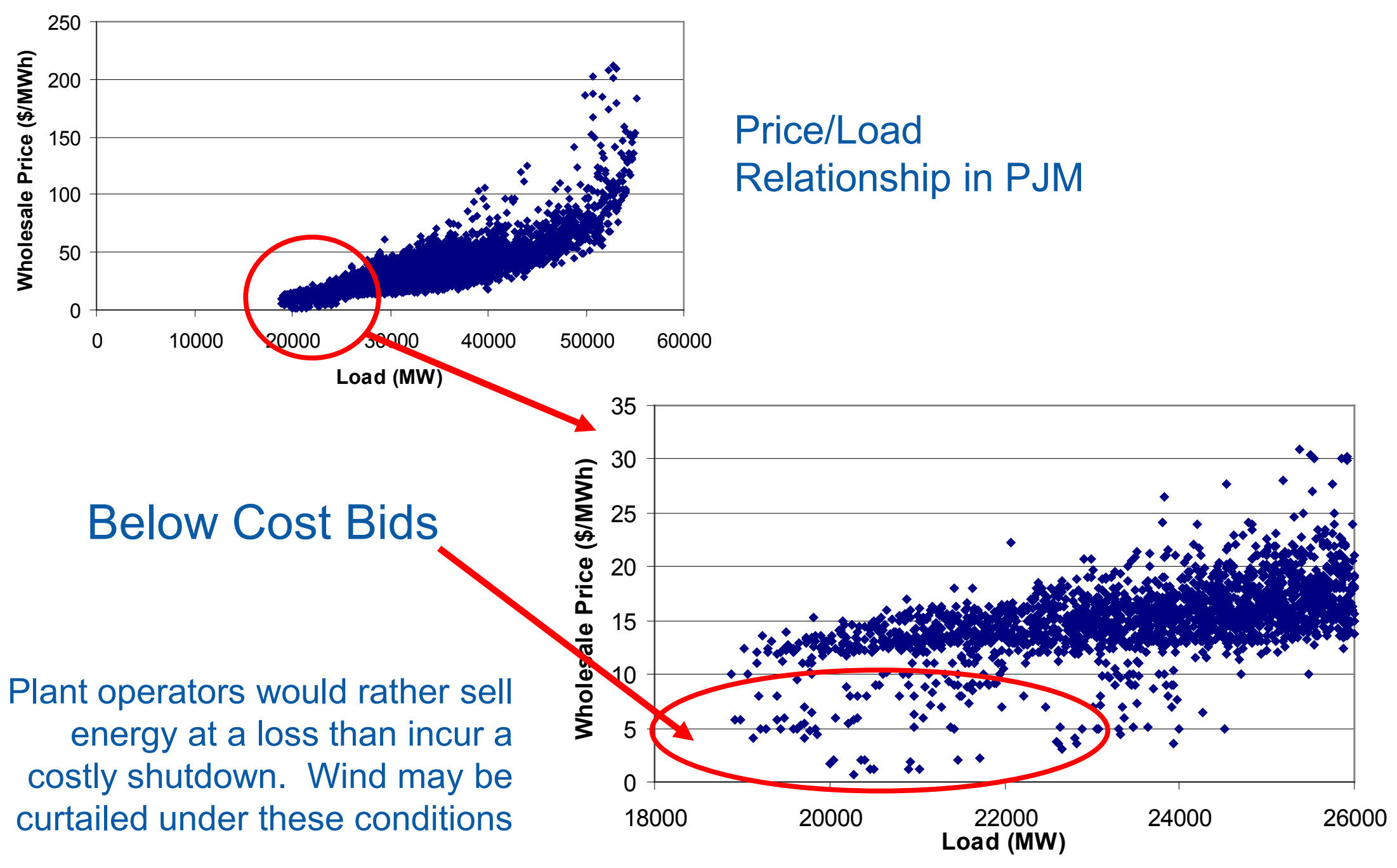




\section{Increased Flexibility is Required}

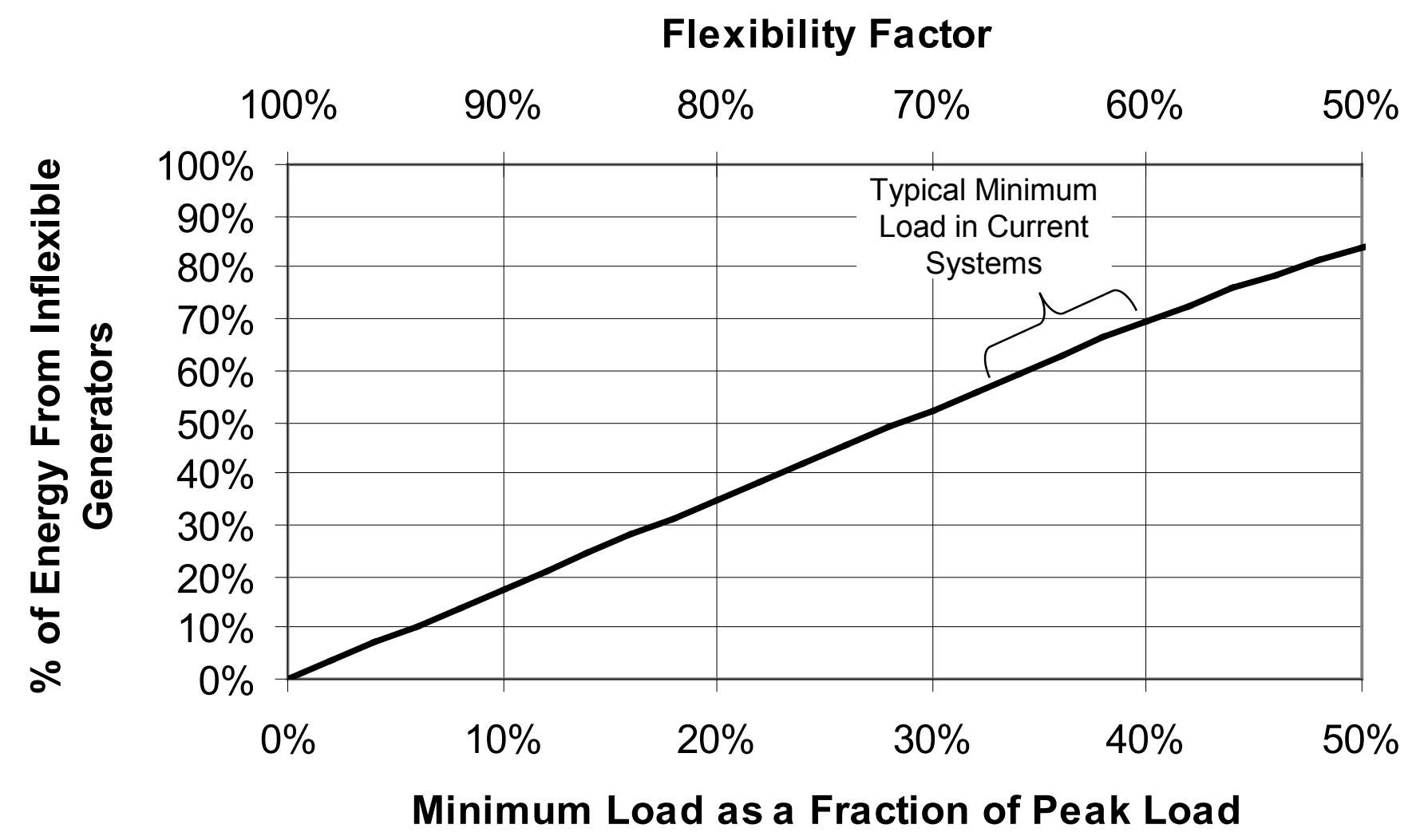

At current minimum loads, baseload generators provide $60-70 \%$ of generation, leaving only $30 \%-40 \%$ for VG. 


\section{Decreased Minimum Load}

Needed to accommodate greater amounts of VG without significant curtailment

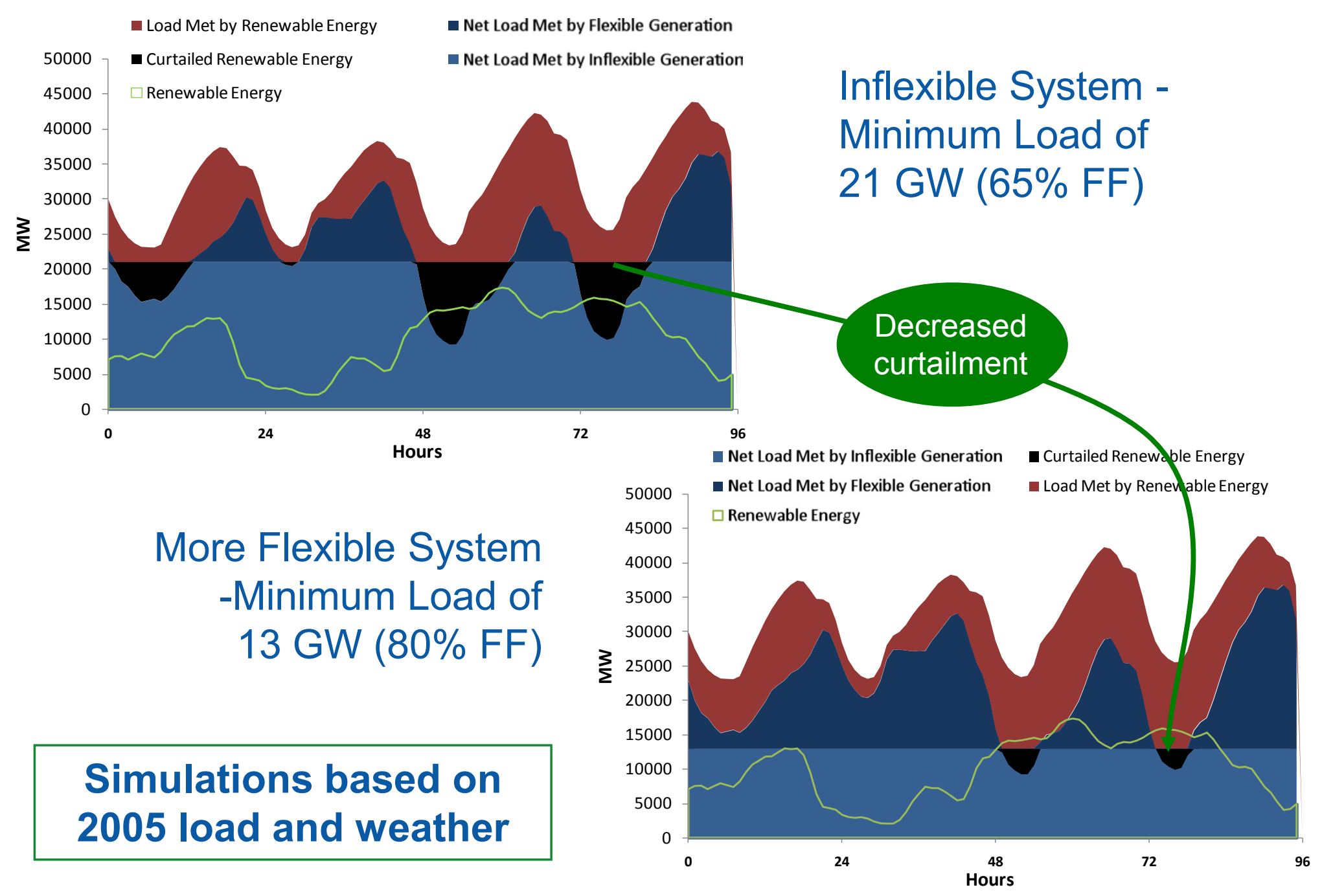




\section{Curtailment as a Function of Flexibility}

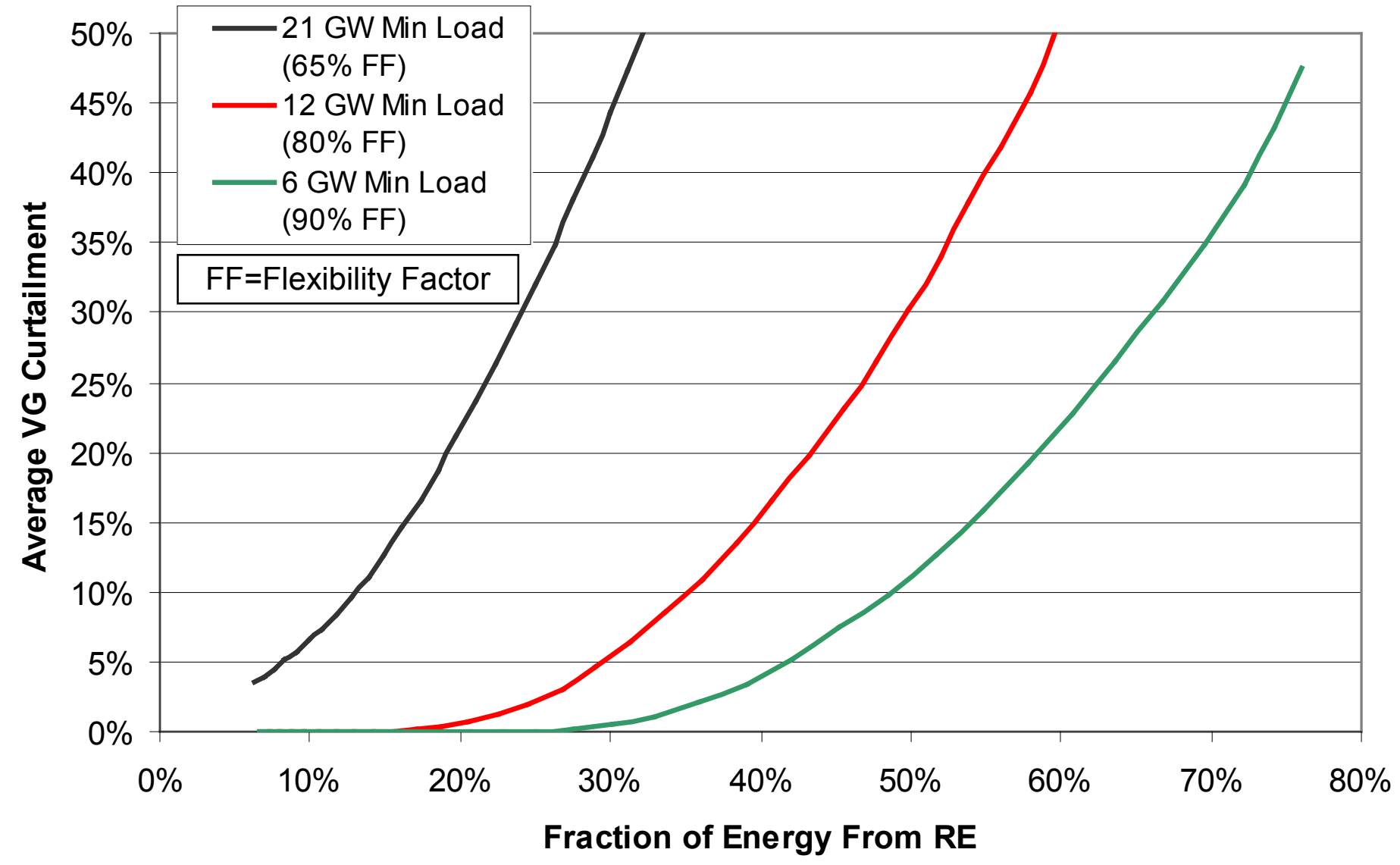

Average curtailment rate as a function of VG penetration for different flexibilities in ERCOT 


\section{Curtailment as a Function of Flexibility (cont.)}

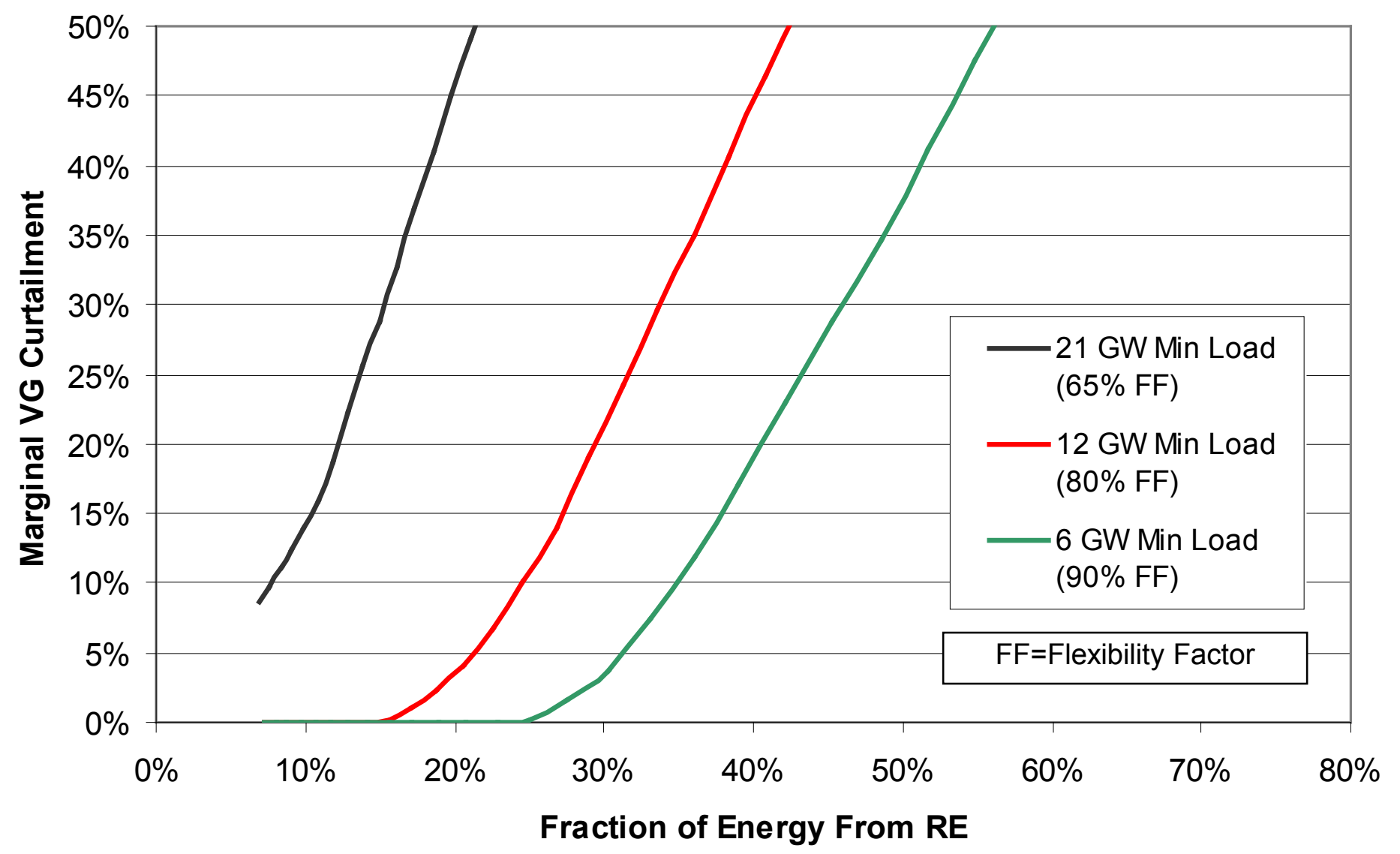

Marginal curtailment rate as a function of VG penetration for different system flexibilities in ERCOT (marginal curtailment is defined as the percentage curtailed as a function of the incremental penetration) 


\section{VG Curtailment}

\section{May Result In Unacceptably High Costs at High Penetration}

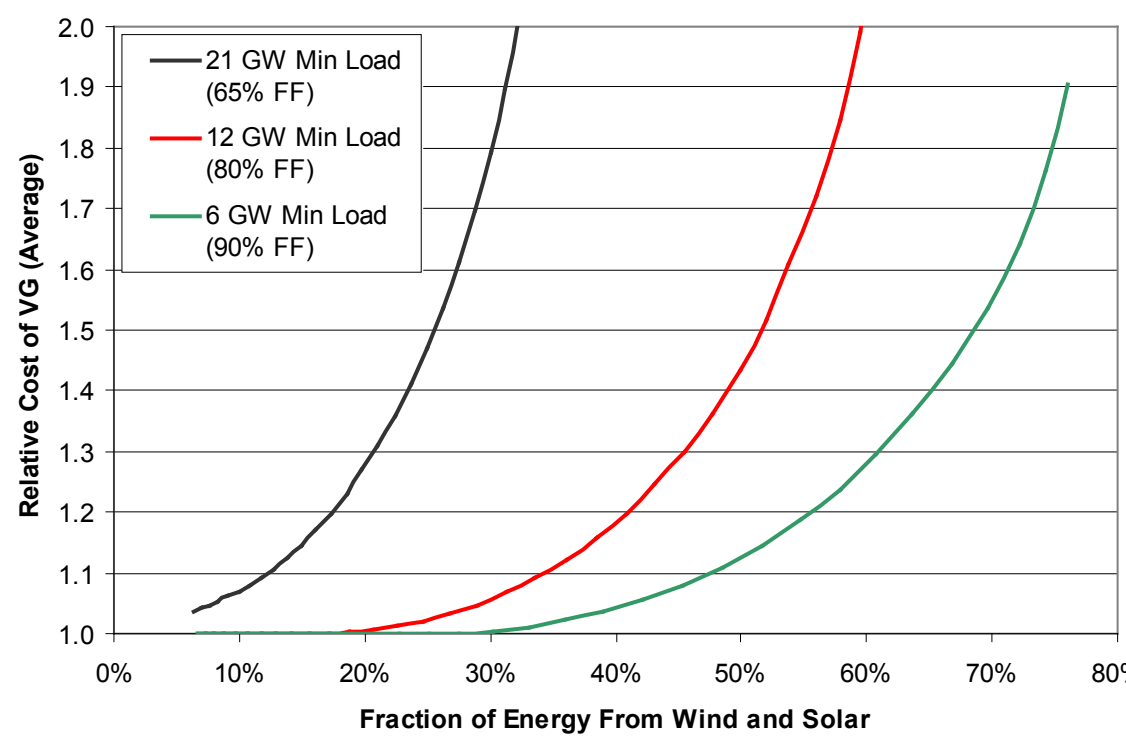

Relative cost of VG - average (top chart) and marginal (bottom chart) - as a function of $V G$ penetration for different system flexibilities in ERCOT

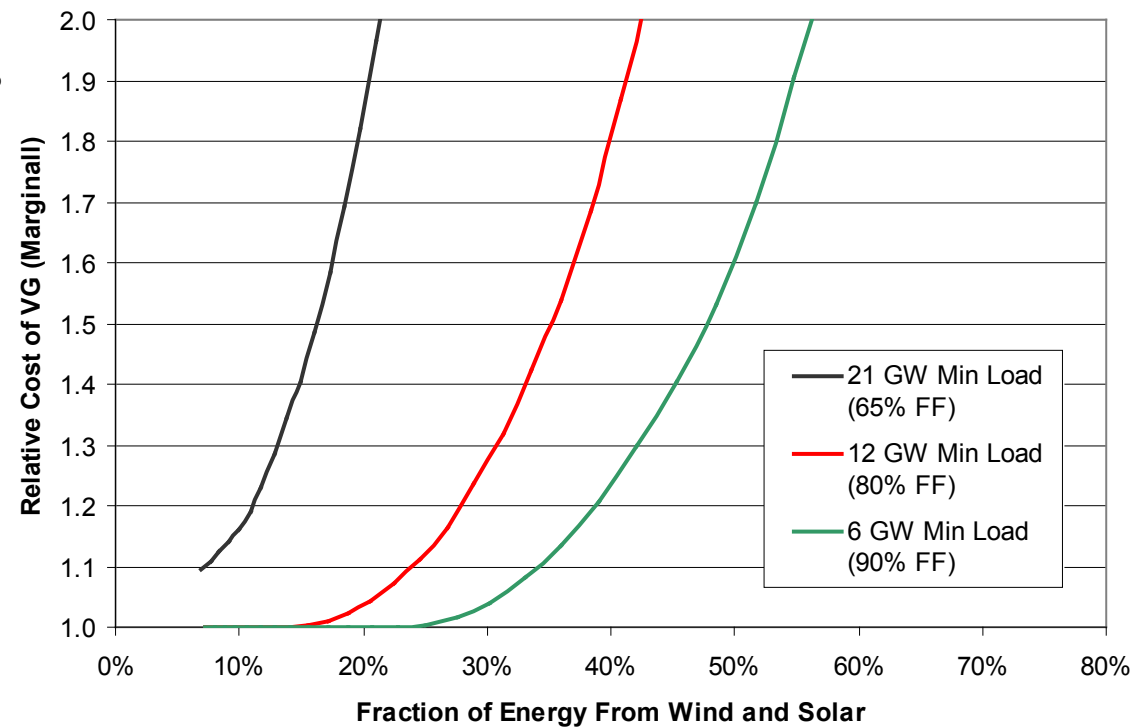




\section{Renewables-Driven Grid Applications}

Storage and Flexibility Options

- At high penetration of VG, additional flexibility is required

- What are the options? 


\section{Renewables-Driven Grid Applications}

\section{Storage and Flexibility Options (cont.)}

While storage provides an "obvious" answer to the problem of supply-demand coincidence, there are a number of options

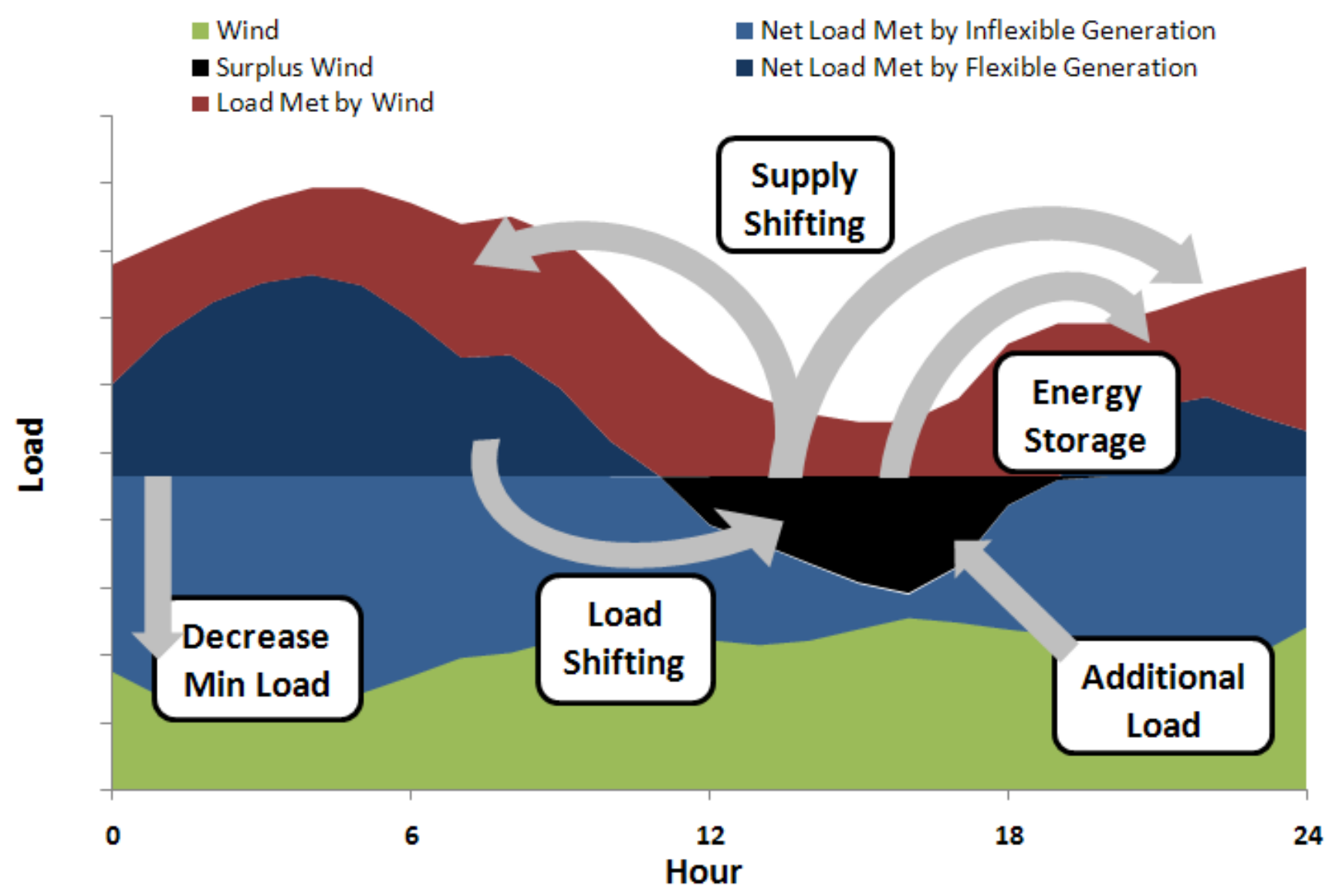




\section{Flexibility Supply Curve}

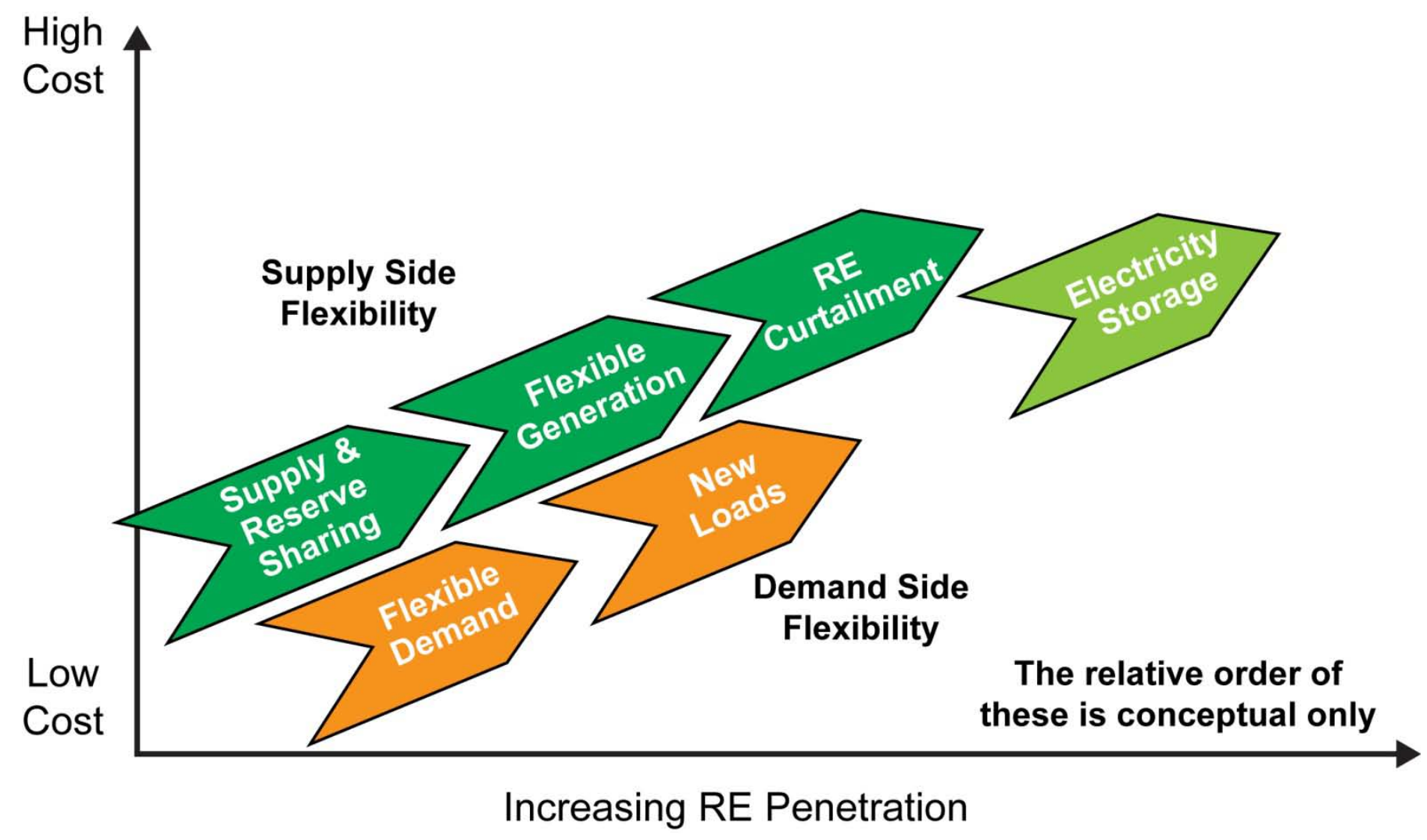

The cost of all options has yet to be determined. Currently, energy storage is expensive and incurs the penalty of round-trip losses.

Based on an original by Nickell 2008 


\section{Energy Storage Can Reduce VG Curtailment}

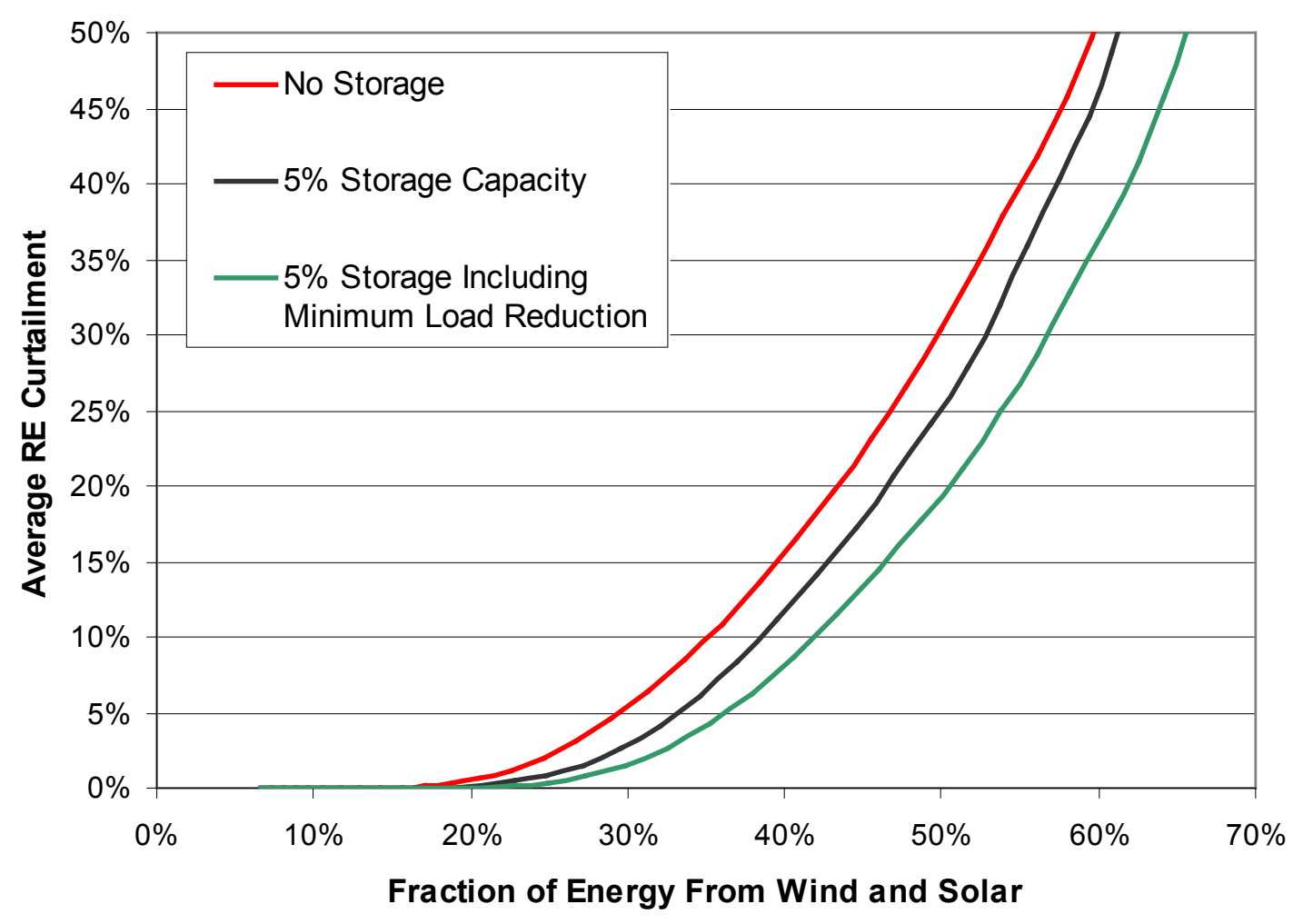

$\mathrm{FF}=80 \%$ (12 GW min load)

Energy storage can reduce curtailment both by shifting otherwise unusable generation, and also increase system flexibility by providing reserves (reducing the need for partially loaded thermal generators) and replacing "must-run" capacity 


\section{Dedicated Renewable Storage?}

- Dedicated renewable storage is generally a nonoptimal use

- Could have scenarios where one storage device is charging while another is discharging simultaneously in the same system

- "Renewable specific" applications are already typically captured in grid operations

\begin{tabular}{|l|l|}
\hline RE Specific Application & "Whole Grid” Application \\
\hline Transmission Curtailment & Transmission Deferral \\
\hline Time Shifting & Load Leveling/Arbitrage \\
\hline Forecast Hedging & Forecast Error \\
\hline Frequency Support & Frequency Regulation \\
\hline Fluctuation Suppression & Transient Stability \\
\hline
\end{tabular}




\section{Storage Technologies}

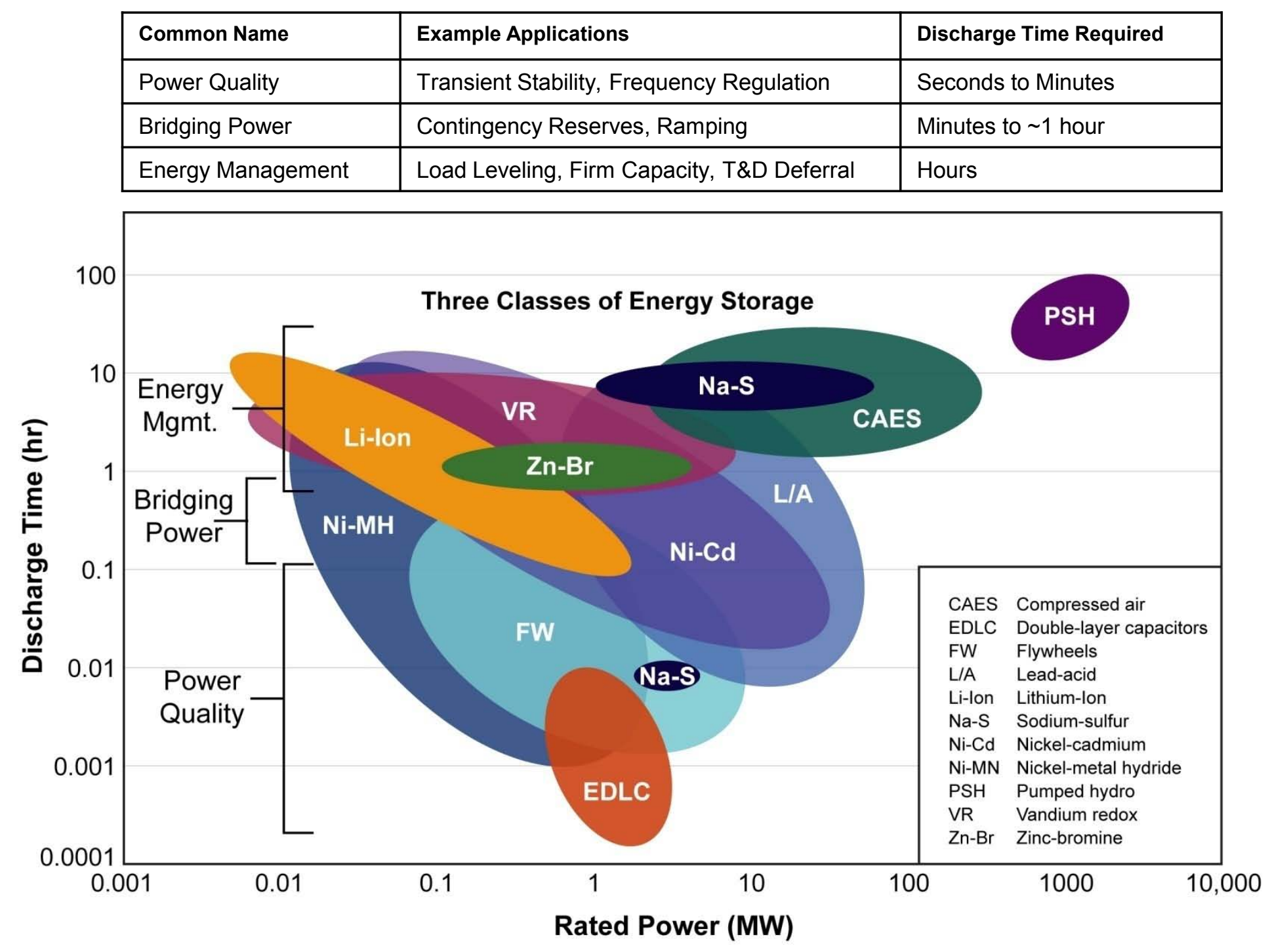

Not shown - thermal storage in end use and in CSP plants 


\section{Caveats}

- Efficiency

- Not uniformly defined (should be AC-AC, but sometimes stated in terms of DC-DC, which doesn't capture conversion)

- May not include parasitics

- CAES (which uses natural gas) and thermal storage cannot be easily compared to pure electricity storage devices such as pumped hydro

- Cost

- Many technologies have not been deployed as large scale, so costs are largely unknown

- Commodity prices affect estimates from different years

- Difficult to compare devices that offer different services (power vs. energy) 


\section{Storage Devices for Power Quality}

- Requires response time of seconds or less, discharge time of up to 10 minutes

- Flywheels

- Currently targeted toward frequency

- Regulation applications

- Capacitors

- Limited deployment to date (low energy capacity)

- Superconducting Magnetic Energy Storage (SMES)

- Limited deployment to date due to high cost and low energy density 


\section{Storage Devices for Bridging Power}

- Rapid response (seconds to minutes)

- Discharge time of up to 1 hour

- May also provide power quality services

- Several battery technologies

- lead-acid

- nickel-cadmium

- nickel-metal hydride

- lithium-ion 


\section{Storage Devices for Energy Management}

- Discharge time of several hours

- Some technologies also provide power quality and bridging power

- Would be the most important class of storage devices for decreasing VG curtailment

- High energy batteries

- Pumped hydro

- Compressed Air

- Thermal Storage 


\section{High Energy Batteries}

- High-temperature batteries

- Sodium sulfur - the most widely deployed battery with more than $270 \mathrm{MW}$ installed

- Sodium-nickel chloride (early commercialization stage)

- Liquid electrolyte "flow" batteries

- Feature separate power and energy components

- All in the early commercialization stage

- Vanadium redox

- Zinc-bromine

- Other chemistries being pursued 


\section{Pumped Hydro Storage}

- Only technology deployed on a gigawatt scale

- $20 \mathrm{GW}$ in the U.S. at 29 sites

- $100 \mathrm{GW}$ worldwide

- Installations in the U.S. range from $<50 \mathrm{MW}$ to 2,100 MW

- Can exceed $75 \%$ AC-AC round-trip efficiency

- Permitting is difficult and time-consuming, but $\sim 30 \mathrm{GW}$ of proposed new capacity in the U.S.

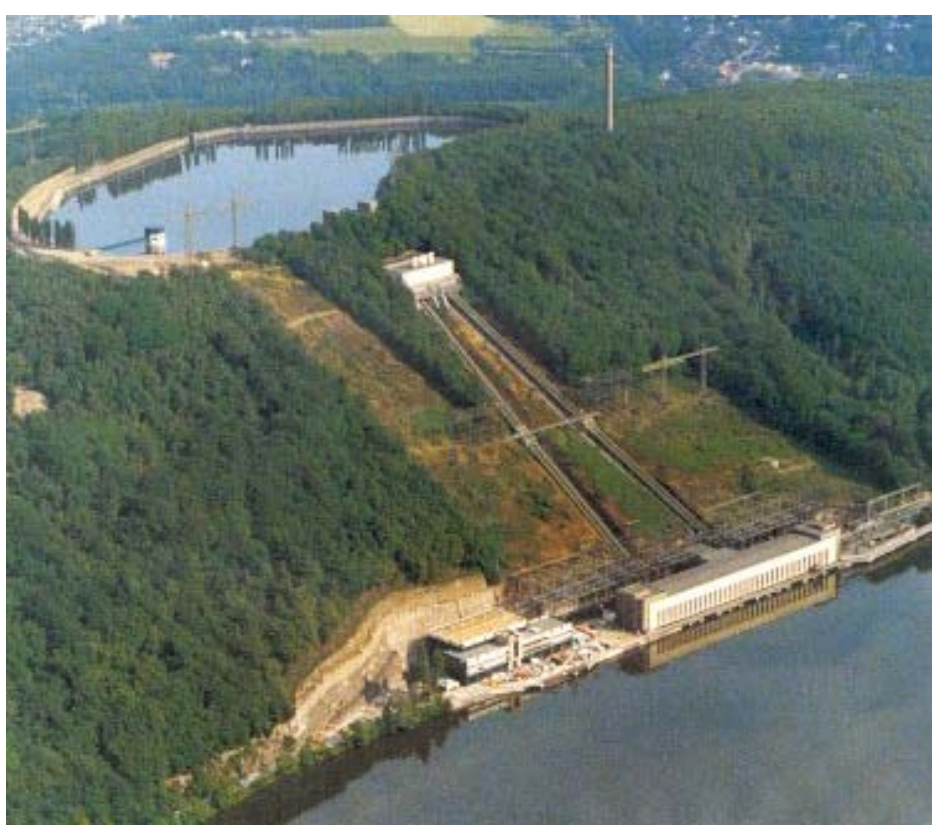




\section{Compressed Air Energy Storage (CAES)}

- Hybrid technology that a gas turbine and burns natural gas

- Single point efficiency not easily defined

- Better to use electricity energy ratio $(0.6-0.8 \mathrm{kWh}$ in per $\mathrm{kWh}$ out) and heat rate (4000-4300 BTU/kWh)

- Two sites - U.S. (110 MW) and Germany (270 MW)

- Alternative designs proposed including adiabatic (no fuel input)

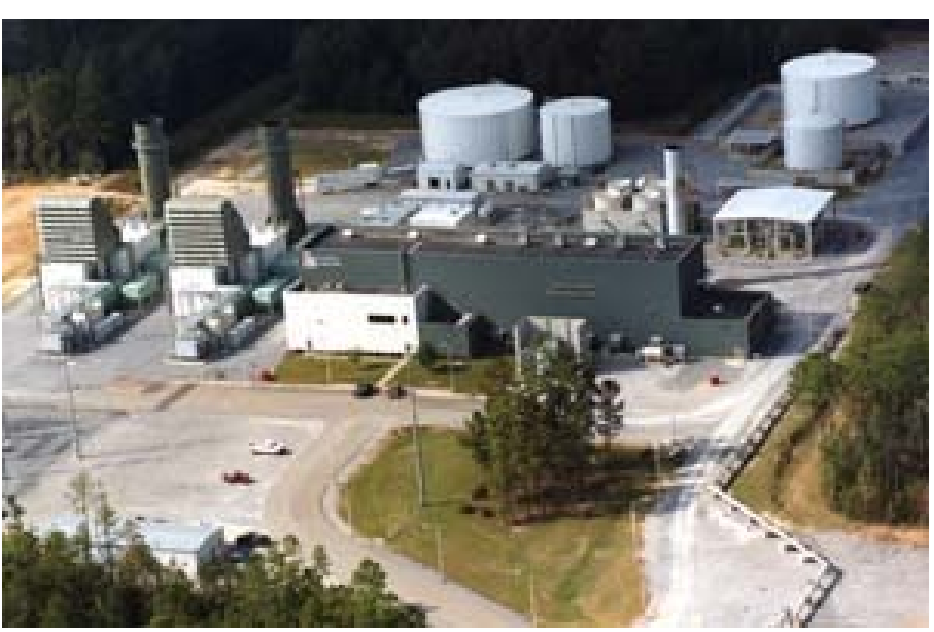




\section{Thermal Storage}

- End-use thermal storage in buildings

- Hot or cold

- Very high round-trip efficiencies (near 100\% in some applications)

- Commercially available

- Thermal storage for CSP

- Very high round-trip efficiency (stores energy before Carnot losses)

- Both applications are tied to a specific use and difficult to compare to more flexible storage technologies 


\section{Electric Vehicles and Vehicle-to-Grid}

- Potential valuable source of distributed storage

- More likely to be used for ancillary services than bulk energy shifting due to high battery cost

- Active area of research 


\section{Conclusions}

- The role of storage is an economic issue - does the value of storage exceed its benefits?

- Storage is undervalued in existing markets and it is still difficult to assess the true value and opportunities for energy storage in the current and future grid

- Renewables increase the value of storage, but the current grid can accommodate substantially increased amount of renewables with options that appear to be lower cost than new dedicated storage

- At penetrations of wind and solar that exceed $30 \%$, increased curtailment will require new sources of grid flexibility

- New models and analysis will be required to evaluate the benefits of energy storage in the future electric grid. 


\section{For More Information}

Full Report:

Denholm, P.; Ela, E.; Kirby, B.; Milligan, M. (2010). Role of Energy Storage with Renewable Electricity Generation. NREL Report No. TP-6A2-47187.

Available at: http://www.nrel.gov/docs/fy10osti/47187.pdf 